\title{
Sex Disparities in Asthma Development and Clinical Outcomes: Implications for Treatment Strategies
}

\author{
Guo-Qiang Zhang $\mathbb{D}^{\prime}$, Saliha Selin Özuygur Ermis $\mathbb{D}^{1,2}$, Madeleine Rådinger (D)', \\ Apostolos Bossios $\mathbb{D}^{3,4}$, Hannu Kankaanranta $\mathbb{D}^{1,5,6}$, Bright Nwaru $\mathbb{D}^{1,7}$ \\ 'Krefting Research Centre, Institute of Medicine, Sahlgrenska Academy, University of Gothenburg, Gothenburg, Sweden; ${ }^{2}$ Department of Respiratory \\ Medicine, Dokuz Eylul University, İzmir, Turkey; ${ }^{3}$ Department of Respiratory Medicine and Allergy, Karolinska University Hospital, Stockholm, \\ Sweden; ${ }^{4}$ Department of Medicine, Huddinge, Karolinska Institutet, Stockholm, Sweden; ${ }^{5}$ Department of Respiratory Medicine, Seinäjoki Central \\ Hospital, Seinäjoki, Finland; ${ }^{6}$ Faculty of Medicine and Health Technology, University of Tampere, Tampere, Finland; ${ }^{7}$ Wallenberg Centre for Molecular \\ and Translational Medicine, University of Gothenburg, Gothenburg, Sweden
}

Correspondence: Bright Nwaru, Krefting Research Centre, Institute of Medicine, Sahlgrenska Academy, University of Gothenburg, P.O. Box 424, Gothenburg, SE-405 30, Sweden, Tel +46076 064 2614, Email bright.nwaru@gu.se

\begin{abstract}
A gender-related disparity exists in asthma morbidity and mortality, which shifts at around puberty from a male predominance to a female predominance. This is clinically reflected in the fact that asthma that occurs in childhood (childhoodonset asthma) mainly affects boys, and that asthma that occurs in adulthood (adult-onset asthma) mainly affects women. Adult-onset asthma is often non-atopic, more severe, and associated with a poorer prognosis, thus posing a marked burden to women's health and healthcare system. Many factors have been indicated to explain this gender-related disparity, including sociocultural and environmental factors as well as biological sex differences (genetic, pulmonary and immunological factors). It has long been suggested that sex hormones may be implicated in at least these biological sex differences. Overall, the evidence remains equivocal for the role of most sex hormones in asthma pathogenesis and clinical outcomes. Well-designed randomized clinical trials are required assessing the potential preventive or therapeutic effects of hormonal contraceptives on asthma in women, thereby helping to advance the evidence to inform future practice guidelines. The mechanisms underlying the role of sex hormones in asthma are complex, and our understanding is not yet complete. Additional mechanistic studies elucidating sex hormone signaling pathways and their interactions involved in the pathogenesis and clinical manifestations of asthma will help to identify potential sex hormone-driven asthma endotypes and novel therapeutic targets, providing the basis for a more personalized asthma management strategy.
\end{abstract}

Keywords: androgen, asthma, estrogen, progestogen, sex disparity, sex hormone

\section{Age- and Gender-Related Disparities in Asthma}

Asthma is a common, heterogenous disease characterized by reversible airway obstruction afflicting around $1-18 \%$ of the population in different countries. ${ }^{1}$ It is estimated that in 2019 asthma affected around 262 million people and caused 461 thousand deaths worldwide, ${ }^{2}$ constituting a major global health problem. For decades, an age- and gender-related difference in asthma has been reported across different continents. During childhood, asthma is more common and severe in boys than in girls. ${ }^{3-19}$ Then, a shift takes place around puberty from which time asthma becomes more common and severe in women than in men. ${ }^{3-5,7,9-33}$

\section{Childhood-Onset and Adult-Onset Asthma}

The switch in asthma from a male predominance in childhood to a female predominance from puberty onwards is clinically reflected in the fact that asthma that occurs in childhood (childhood-onset asthma) mainly affects boys, whilst asthma that occurs in adulthood (adult-onset asthma) mainly affects women., ${ }^{9,10,17,18}$ Although a specific age cut-off for adult-onset asthma has not been determined, the estimated incidence of adult-onset asthma from general population 
cohort studies has been reported to be on average 5.9 cases per 1000 person-years in women and 4.4 cases per 1000 person-years in men. ${ }^{24}$ Compared to childhood-onset asthma, adult-onset asthma is often non-atopic, more severe, and associated with persistent airflow limitation, a faster decline in lung function and a poorer prognosis, thereby representing a distinct clinical phenotype of asthma. ${ }^{34-39}$ The age at onset of asthma is a critical determinant of asthma remission such that asthma remission becomes rarer as the age at onset of asthma increases. ${ }^{10,40}$ Childhood-onset asthma has a high remission probability reaching up to $60 \%,{ }^{10}$ whereas adult-onset asthma tends to be chronic and has a considerably low remission probability ranging from $3 \%$ to $18 \%{ }^{10,40-45}$ Due to the low remission probability of adult-onset asthma together with the relatively high incidence among women, adult-onset asthma became the dominant phenotype among women with asthma early by age $32-40$ years in a US study (adult-onset asthma defined as age at onset of $\geq 18$ years), ${ }^{46}$ and by age $30-38$ years in two Finnish studies (age at onset of $\geq 15$ or 18 years), ${ }^{17,18}$ while childhood-onset asthma remained the dominant phenotype among men with asthma by age $50-54$ years. ${ }^{17,18}$ These studies indicate that adultonset asthma poses a marked burden to women's health, healthcare system and the larger society.

\section{Hypotheses Linking Sex Hormones and Asthma}

Several hypotheses have been proposed to explain the age- and gender-related variations in asthma, including sociocultural and environmental factors as well as biological sex differences (genetic, pulmonary and immunological factors). ${ }^{47}$ Because the switch in asthma incidence and clinical morbidity between males and females coincides with the onset of puberty, which involves different increases in the activities of sex hormones (estrogens, progestogens and androgens), sex hormones have been suggested to play a major role in theses biological sex differences. ${ }^{47,48}$ In reproductive-age women, the key hormonal transition points including puberty, menstruation and pregnancy which are characterized by increases/fluctuations in the levels of endogenous sex hormones, may increase the risk of developing asthma and worsening of clinical outcomes, whereas suppression of the activities of endogenous sex hormones (eg, through hormonal contraceptives) may decrease the risk. In menopausal women, the onset of menopause and thus a reduction in the activities of endogenous sex hormones may decrease the risk of developing asthma and improve clinical outcomes, whereas use of menopausal hormone therapy (MHT) to enhance the levels of endogenous sex hormones may increase the risk and worsen clinical outcomes. In addition, male sex hormones (androgens) may confer a protective effect on the susceptibility to asthma. ${ }^{49}$ In all, the ratio of female sex hormones to male sex hormones may play a crucial role in the pathogenesis and clinical manifestations of asthma. Although these hypotheses seem intriguing and promising, from decades of intensive investigations evidence linking sex hormones to asthma remains equivocal. ${ }^{48,50,51}$ In this review, we summarize the evidence on the potential role of sex hormones in asthma pathogenesis and its clinical manifestations from epidemiological, clinical, and experimental studies, with a particular focus on epidemiological and clinical data in females. We also discuss the potential clinical implications of sex hormones in asthma prevention and management, and provide some perspectives for future research in this area. Table 1 and Table 2 respectively summarize the epidemiological evidence on the role of sex hormones in asthma onset and clinical outcomes.

\section{Epidemiological Evidence on Sex Hormones and Asthma Onset Puberty}

A systematic review including six prospective cohort studies with 18,272 women found that compared to typical menarche (11-13 years), early menarche ( $<11$ years) was associated with increased odds of new-onset asthma after puberty (odds ratio [OR] 1.49, 95\% confidence interval [CI] 1.14-1.94). ${ }^{51}$ The results were further supported by Mendelian randomization (MR) studies, ${ }^{52,53}$ in which genetic variants known to affect age at puberty were used as proxies (ie, instrumental variables assumed not to be affected by typical confounding factors or reverse causation ${ }^{54}$ ) to estimate the causal effect of age at puberty on asthma onset. From the UK Biobank study, ${ }^{52}$ MR analyses based on 243,316 women aged 40-69 years using 254 genetic variants for age at menarche found that compared with normal menarche (12-14 years), early menarche ( $<12$ years) was associated with an $8 \%$ increase (OR $1.08,95 \%$ CI $1.04-1.12$ ) and late menarche ( $>14$ years) with an $8 \%$ decrease (OR $0.92,95 \%$ CI $0.89-0.97$ ) in asthma odds, suggesting a continuous protective effect of increasing age at puberty. MR analyses of the data from the Taiwan Children Health 
Table I Summary of Epidemiological Evidence on Sex Hormones and Asthma Onset

\begin{tabular}{|c|c|}
\hline Exposure & Epidemiological Evidence \\
\hline Puberty & $\begin{array}{l}\text { A systematic review }{ }^{51} \text { including six cohort studies with } 18,272 \text { women reported that compared to typical } \\
\text { menarche ( } 1 \text { I-13 years), early menarche }(<11 \text { years) was associated with an increased risk of new-onset asthma } \\
\text { after puberty. Two MR studies }{ }^{52,53} \text { found similar results. }\end{array}$ \\
\hline Menstruation & $\begin{array}{l}\text { A systematic review }{ }^{51} \text { including three cross-sectional studies reported that compared to regular menstruation, } \\
\text { irregular menstruation was associated with increased odds of current asthma. However, because of the cross- } \\
\text { sectional design, causal inference is impossible. }\end{array}$ \\
\hline Pregnancy & $\begin{array}{l}\text { Three cross-sectional studies }{ }^{56-58} \text { investigated association between pregnancy history and asthma odds, but } \\
\text { reported inconsistent results. Likewise, causal inference is impossible because of the cross-sectional design. }\end{array}$ \\
\hline Menopause & $\begin{array}{l}\text { Conflicting evidence exists for menopause and asthma: the UK national cohort study }{ }^{62} \text { of } 353,173 \text { women and the } \\
\text { Nurses' Health Study }{ }^{59} \text { of } 64,237 \text { women reported that postmenopausal women had a decreased risk of new-onset } \\
\text { asthma compared to pre- or peri-menopausal women; by contrast, the French E3N cohort study }{ }^{61} \text { of } 67,872 \\
\text { women and the Respiratory Health in Northern Europe study }{ }^{60} \text { of } 2322 \text { women found that compared to } \\
\text { premenopausal women, peri- or post-menopausal women had an increased asthma risk. }\end{array}$ \\
\hline Hormonal contraceptives & $\begin{array}{l}\text { The evidence on hormonal contraceptives and asthma is mixed: the UK national cohort study }{ }^{64} \text { of } 564,896 \text { women } \\
\text { and a German community-based cohort study }{ }^{63} \text { of } 1191 \text { women reported that use of hormonal contraceptives was } \\
\text { associated with a decreased risk of new-onset asthma compared to non-use, and that longer duration of use was } \\
\text { associated with a lower asthma risk than shorter duration }{ }^{64} \text {; however, the Nurses' Health Study }{ }^{59} \text { of } 36,094 \\
\text { women found that use of hormonal contraceptives was associated with an increased asthma risk. }\end{array}$ \\
\hline $\begin{array}{l}\text { Menopausal hormone } \\
\text { therapy }(\mathrm{MHT})\end{array}$ & $\begin{array}{l}\text { The evidence on MHT and asthma is mixed: an umbrella review }{ }^{65} \text { including five cohort studies with } 163,16 \mathrm{I} \text { women } \\
\text { and a Danish register-based nested case-control study }{ }^{66} \text { of } 379,649 \text { women reported that use of MHT was } \\
\text { associated with an increased risk of new-onset asthma compared to non-use; however, the UK national cohort } \\
\text { study }^{62} \text { of } 353,173 \text { women found that use of MHT was associated with a decreased asthma risk, and that longer } \\
\text { duration of use was associated with a lower asthma risk than shorter duration. }\end{array}$ \\
\hline $\begin{array}{l}\text { Serum levels of sex } \\
\text { hormones }\end{array}$ & $\begin{array}{l}\text { A cross-sectional study }{ }^{67} \text { reported that an elevated serum level of estradiol was associated with decreased odds of } \\
\text { current asthma in both women and men. Three cross-sectional studies }{ }^{67-69} \text { found that an elevated serum level of } \\
\text { (free) testosterone was associated with decreased odds of asthma in females and/or males. However, causal } \\
\text { inference is impossible because of the cross-sectional design. }\end{array}$ \\
\hline
\end{tabular}

Abbreviations: MHT, menopausal hormone therapy; MR, Mendelian randomization.

Study of 1475 girls aged 11-12 years using six genetic variants for early pubertal maturation reported that early puberty was associated with a tendency towards increased asthma odds (OR 1.11, 95\% CI 0.83-1.48). ${ }^{53}$ Interestingly, a similar pattern between puberty and asthma was also observed in males, with increased odds of asthma for early puberty and decreased odds for late puberty. ${ }^{52,53}$ Possible explanations may include greater cumulative exposure to female sex hormones due to early puberty in females as well as other biological and psychological factors that accompany early puberty in both males and females. ${ }^{52,55}$

\section{Menstruation}

A systematic review including three cross-sectional studies with 9202 women found that compared to regular menstruation, irregular menstruation was associated with increased odds of current asthma (OR 1.59, 95\% CI 1.23-2.05). ${ }^{51}$ However, due to the cross-sectional design, we cannot assume any causal relationship in these results.

\section{Pregnancy}

Evidence on pregnancy and asthma onset is sparse. Cross-sectional analysis of the data from the Tasmanian Longitudinal Health Study (TAHS) of 388 women aged 29-32 years suggested that odds of current asthma increased with number of live births in parous women (OR 1.50 per birth, 95\% CI 1.01-2.23). ${ }^{56}$ However, further cross-sectional analysis of the 
Table 2 Summary of Epidemiological Evidence on Sex Hormones and Asthma Progression and Clinical Outcomes

\begin{tabular}{|c|c|}
\hline Exposure & Epidemiological Evidence \\
\hline Puberty & $\begin{array}{l}\text { The Childhood Asthma Management Program study }{ }^{71} \text { prospectively tracked } 418 \text { children with asthma through } \\
\text { childhood and adolescence, and found that asthma symptoms tended to worsen in girls but improve in boys. }\end{array}$ \\
\hline Menstruation & $\begin{array}{l}\text { Around } 10-40 \% \text { of women with asthma experience cyclical worsening of asthma symptoms during the } \\
\text { perimenstrual period, a phenomenon known as perimenstrual asthma (PMA) }{ }^{72-75} \text { The pathophysiological } \\
\text { mechanisms of PMA remain poorly understood. }\end{array}$ \\
\hline Pregnancy & $\begin{array}{l}\text { During pregnancy, approximately one third of women with asthma experience improvement, one third show } \\
\text { worsening of symptoms, and one third remain unchanged. }{ }^{83-86} \text { Asthma tends to return to the pre-pregnancy state } \\
\text { after delivery. }{ }^{91-93} \text { Some studies }{ }^{88,90,97,100-106} \text { investigated association between fetal gender and maternal asthma, } \\
\text { but reported inconsistent results. }\end{array}$ \\
\hline Menopause & $\begin{array}{l}\text { To our best knowledge, no studies have investigated asthma progression during menopausal transition among } \\
\text { women with asthma. Several longitudinal studies }{ }^{107-110} \text { and a MR study }{ }^{1 / 1} \text { looked at the trajectory of lung function } \\
\text { during menopausal transition among healthy women, but reported contradictory results. }\end{array}$ \\
\hline Hormonal contraceptives & $\begin{array}{l}\text { Among asthmatic patients, the UK national cohort study }{ }^{118} \text { of } 83,084 \text { women and the Children's Health Study }{ }^{117} \text { of } \\
192 \text { women found that use of hormonal contraceptives was associated with a decreased risk of severe asthma } \\
\text { exacerbations or wheezing symptoms compared to non-use. The therapeutic effects of hormonal contraceptives } \\
\text { on PMA were reported in several case reports and series, }{ }^{81,112,113} \text { but not in another case report. }\end{array}$ \\
\hline $\begin{array}{l}\text { Menopausal hormone } \\
\text { therapy (MHT) }\end{array}$ & $\begin{array}{l}\text { The UK national cohort study }{ }^{124} \text { of } 31,656 \text { women with asthma found that use of MHT was associated with an } \\
\text { increased risk of severe asthma exacerbations compared to non-use, and that longer duration of use was associated } \\
\text { with a higher risk of asthma exacerbations than shorter duration. Several uncontrolled before-and-after studies } \\
{ }^{121} \text { investigated the effects of MHT on lung function or asthma medication use in women with asthma, but reported } \\
\text { conflicting results. }\end{array}$ \\
\hline $\begin{array}{l}\text { Serum levels of sex } \\
\text { hormones }\end{array}$ & $\begin{array}{l}\text { Among asthmatic patients, a cross-sectional study }{ }^{125} \text { reported that an elevated serum level of estradiol was } \\
\text { associated with decreased lung function in girls. Three cross-sectional studies }{ }^{68,69,125} \text { found that an elevated serum } \\
\text { level of (free) testosterone or DHEAS was associated with increased lung function and/or deceased odds of asthma } \\
\text { symptoms in females and/or males. However, causal inference is impossible because of the cross-sectional design. }\end{array}$ \\
\hline
\end{tabular}

Abbreviations: DHEAS, dehydroepiandrosterone sulfate; MHT, menopausal hormone therapy; MR, Mendelian randomization; PMA, perimenstrual asthma.

TAHS data of 2764 women aged 44 years found no evidence of association between pregnancy history (number of live births and age at first pregnancy) and current asthma. ${ }^{57}$ Similarly, in another cross-sectional study of 1755 non-smoking women aged 35-74 years, ${ }^{58}$ no evidence of association was found between asthma and number of pregnancies or number of live births. Likewise, causal inference is impossible because of the cross-sectional design in these studies.

\section{Menopause}

Conflicting evidence exists for the impact of menopause on asthma onset. The Nurses' Health Study of 64,237 women aged 34-68 years with 425,787 person-years of follow-up reported that compared with premenopausal women, naturally postmenopausal women who were never users of MHT had a decreased risk of developing asthma (hazard ratio [HR] 0.65, 95\% CI 0.46-0.92). ${ }^{59}$ This result was subsequently contradicted by two other prospective cohort studies. ${ }^{60,61}$ The Respiratory Health in Northern Europe study of 2322 women aged 45-65 years reported that peri- or post-menopausal women experienced increased odds of asthma compared to premenopausal women, with ORs ranging from 2.11 to 3.44. ${ }^{60}$ The French E3N cohort study of 67,872 women aged 41-68 years found that naturally peri- or post-menopausal women who were overweight or obese as well as surgically postmenopausal women had an increased risk of asthma compared to premenopausal women, with HRs ranging from 1.33 to $2.08{ }^{61}$ However, in a recent UK national retrospective cohort study of 353,173 women aged 46-70 years with 1,340,423 person-years of follow-up, ${ }^{62}$ postmenopausal women were found to have a decreased risk of developing asthma compared to perimenopausal women (HR 0.88, 95\% CI 0.83-0.92). 


\section{Hormonal Contraceptives}

Current evidence on hormonal contraceptives and asthma is mixed. The Nurses' Health Study of 36,094 postmenopausal women with 295,694 person-years of follow-up reported that past use of hormonal contraceptives was associated with an increased risk of developing asthma compared to non-use (HR 1.57, 95\% CI 1.16-2.12). ${ }^{59}$ However, this result was contradicted by two subsequent studies. In a German prospective community-based cohort study of 1191 girls aged 9-11 years followed into early adulthood (19-24 years old), ${ }^{63}$ use of hormonal contraceptives was found to be associated with decreased odds of developing asthma (OR 0.27, 95\% CI 0.12-0.58). In a recent national, longitudinal UK cohort study of 564,896 women aged 16-45 years with 3,597,146 person-years of follow-up, ${ }^{64}$ use of hormonal contraceptives and its subtypes (estrogen plus progestin therapy and progestin-only therapy) was associated with a decreased risk of developing asthma, with HRs ranging from 0.59 to 0.70 . Furthermore, longer duration of use was associated with a lower risk of asthma than shorter duration. ${ }^{64}$

\section{Menopausal Hormone Therapy}

The evidence on MHT and new-onset asthma in menopausal women remains mixed. An umbrella review including five prospective cohort studies with 163,161 women reported that MHT use was associated on average with a 1.41-fold (95\% CI 1.09-1.81) increased risk of new-onset asthma compared to non-use. ${ }^{65}$ Similarly, in a recent nested case-control study based on the Danish registers, ${ }^{66}$ which included 34,533 women with asthma and 345,116 without asthma aged 40-65 years, use of MHT and its subtypes (estrogen-alone therapy and estrogen plus progestin therapy) was associated with an increased risk of developing asthma, with HRs ranging from 1.18 to 1.63 . However, these results were contrasted by a UK national retrospective cohort study, ${ }^{62}$ the largest longitudinal study on the topic to date, which included 353,173 women aged 46-70 years with 1,340,423 person-years of follow-up, and found that use of MHT and its subtypes was associated with a decreased risk of asthma, with HRs ranging from 0.78 to 0.89 , and that longer duration of use was associated with a decreased asthma risk in a dose-response manner.

\section{Serum Levels of Sex Hormones}

In a US nationwide cross-sectional study of 7615 adults (3662 women and 3953 men) aged 18-79 years, ${ }^{67}$ elevated serum levels of both free testosterone (the highest quartile [Q4] versus the lowest [Q1]: OR 0.59, 95\% CI 0.37-0.91) and estradiol (Q4 versus Q1: OR $0.43,95 \%$ CI $0.23-0.78$ ) were associated with reduced odds of current asthma in obese women, and an elevated serum estradiol level was associated with reduced odds of current asthma in non-obese men (Q4 versus Q1: OR 0.44, 95\% CI 0.21-0.90). Similarly, in a UK cross-sectional study of 256,419 adults (123,921 women and 132,498 men) aged 40-69 years, ${ }^{68}$ an elevated serum level of free testosterone was associated with reduced odds of physician-diagnosed asthma in both women (Q4 versus Q1: OR 0.67, 95\% CI 0.64-0.71) and men (Q4 versus Q1: OR 0.87, 95\% CI 0.82-0.91). Further, in another US cross-sectional study of 7584 participants ( 3808 females and 3776 males) with a broader age range (6-80 years) ${ }^{69}$ an elevated serum testosterone level was associated with lower odds of current asthma in both females (for each 25-unit change in serum testosterone: OR 0.70, 95\% CI 0.60-0.91) and males (for each 25-unit change in serum testosterone: OR 0.97, 95\% CI 0.94-0.99). Of note, because of the cross-sectional design, causal inference is impossible. Interestingly, a recent two-sample MR study across two large datasets from the Trans-National Asthma Genetics Consortium genome-wide association study of asthma and UK Biobank with over 460,000 individuals, ${ }^{70}$ indicated a protective effect of genetically elevated sex hormone-binding globulin (SHBG) on asthma, with ORs ranging from 0.83 to 0.86 , per unit increase in natural $\log$ SHBG, and that the effect was more pronounced among females than males. However, due to the complex genetic correlation between SHBG and testosterone as well as other hormones (eg, estrogens), further studies are needed to disentangle the downstream effects of SHBG on asthma and the mechanistic pathways involved. $^{70}$

\section{Epidemiological Evidence on Sex Hormones and Asthma Progression and Clinical Outcomes}

\section{Puberty}

Studies on natural progression of asthma through puberty are scant. The Childhood Asthma Management Program study prospectively tracked 418 children (184 girls and 234 boys) aged 5-12 years with mild-to-moderate asthma through 
childhood and adolescence, with daily records of asthma symptoms for five years. ${ }^{71}$ It found that at approximately nine years of age when the Tanner stages (a grading system used for pubertal staging) began to increase, asthma symptoms started to worsen in girls, but not in boys. At late puberty, asthma symptoms continued to worsen in girls, while asthma symptoms started to improve in boys. ${ }^{71}$

\section{Menstruation}

Around $10-40 \%$ of women with asthma experience cyclical worsening of asthma symptoms during the perimenstrual period, a phenomenon known as perimenstrual asthma (PMA). ${ }^{72-75}$ PMA is operationally defined as an aggravation of asthma symptoms or a decrease in lung function immediately preceding or during the menstrual phase of the female cycle. ${ }^{72}$ Women with PMA tend to have increased asthma rescue medication use and more emergency room visits and hospitalizations for asthma, compared to women without PMA. ${ }^{73,76-79}$ Some studies have linked PMA with severe, difficult-to-control asthma or near-fatal and fatal events. ${ }^{74,75,79-82}$ However, the pathophysiological mechanisms of PMA remain poorly understood. In light of the well-known hormonal fluctuations throughout the menstrual cycle and the cyclical nature of PMA, it has been hypothesized that female sex hormones may likely play a pivotal role in PMA, although the potential mechanisms through which sex hormones may influence the course of asthma remain unclear. ${ }^{72}$ If fluctuations in the levels of female sex hormones during the menstrual cycle cause cyclical changes in the severity of asthma, it seems plausible that suppressing the fluctuations through appropriate hormonal contraceptives could reduce the perimenstrual worsening of asthma and improve asthma control in PMA patients. However, there is a paucity of rigorous evidence in this regard; several case reports and series investigated the potential therapeutic effects of hormonal contraceptives on PMA, but yielded discordant results. ${ }^{72}$ A more detailed discussion of the studies is given in a later section on hormonal contraceptives.

\section{Pregnancy}

A number of studies have shown that the course of asthma may change during pregnancy. The commonly quoted generalization is that during pregnancy, approximately one-third of women with asthma experience improvement, onethird show worsening of symptoms, and one-third remain unchanged. ${ }^{83-86}$ Women with severe asthma are more likely to experience exacerbations during pregnancy than those with mild disease ${ }^{86-90}$ After delivery, asthma tends to return to the pre-pregnancy state. ${ }^{91}$ Cases of severe life-threatening asthma improving markedly within 24 hours of termination of pregnancy have also been noted. ${ }^{92,93}$ The mechanisms contributing to the changes in asthma during or after pregnancy are not well understood. In view of the significant changes in sex hormones during pregnancy, sex hormones have been hypothesized to be at least partly responsible for the effects of pregnancy on maternal asthma. ${ }^{94}$ On the other hand, fetal gender has been suggested to alter maternal inflammatory processes associated with asthma, possibly through the differences in maternal levels of sex hormones by fetal gender, such that maternal inflammation is upregulated in the presence of a female fetus. ${ }^{95-99}$ However, studies looking at the effect of fetal gender on the course of asthma during pregnancy reported inconsistent results. Several studies found that during pregnancy women with asthma carrying a female fetus were more likely than those carrying a male fetus to have greater airway lability, ${ }^{100}$ increased steroid use, ${ }^{97,101}$ or asthma exacerbations, ${ }^{102,103}$ but these findings were not replicated in other studies. ${ }^{88,90,104-106}$

\section{Menopause}

To our best knowledge, no studies have looked at the progression of asthma during menopausal transition among women with asthma. Some studies investigated the trajectory of lung function during menopausal transition among healthy women, but reported contradictory results. Several longitudinal studies showed that menopause was associated with reduced lung function parameters (eg, forced vital capacity $[\mathrm{FVC}]$, forced expiratory volume in one second $\left.\left[\mathrm{FEV}_{1}\right]\right) .{ }^{107-110}$ However, MR analyses of 94,742 naturally postmenopausal women from the UK Biobank found that early menopause $\left(<45\right.$ years) was associated with higher $\mathrm{FEV}_{1} / \mathrm{FVC}$ and a lower risk of airflow obstruction (OR 0.85 , $95 \%$ CI $0.82-0.89$ ), compared to normal menopause (45-55 years). ${ }^{111}$ Given that MR study is generally thought to be free from classical confounding, future longitudinal studies which account for more potential confounders as well as 
replication of the MR study across different populations may help to understand the inconsistency between the observational and MR findings.

\section{Hormonal Contraceptives}

Given that hormonal fluctuations during the menstrual cycle might be responsible for cyclical worsening of asthma symptoms among some women with asthma, ${ }^{72}$ several case reports and series explored the potential therapeutic effects of hormonal contraceptives on PMA, but reported inconsistent results. Four patients with severe premenstrual exacerbations of asthma resistant to conventional therapy, including high-dose corticosteroids, responded very well to intramuscular progesterone injections. ${ }^{81,112}$ One case report found that premenstrual exacerbations of asthma improved dramatically following administration of an oral contraceptive consisting of norgestrel and ethinylestradiol. ${ }^{113}$ By contrast, another case report suggested that an oral contraceptive comprising norgestimate and ethinylestradiol may cause deterioration of PMA. ${ }^{114}$ Further, some studies investigated the effects of hormonal contraceptives on lung function or asthma exacerbations among an unselected population of reproductive-age women with asthma. In two small prospective studies of 17-18 women with asthma, ${ }^{115,116}$ women receiving oral combined contraceptive pill compared with those not receiving contraceptive pill had attenuated cyclical change in airway responsiveness to adenosine monophosphate and exhaled nitric oxide levels as well as reduced variations in diurnal peak expiratory flow (PEF), in association with suppression of the normal luteal phase rise in sex hormones. Prospective data from the Children's Health Study of 192 women with a history of asthma aged 13-28 years reported that use of hormonal contraceptives was associated with reduced occurrence of wheezing symptoms (OR $0.18,95 \%$ CI $0.06-0.56$ ), compared to non-use. ${ }^{117}$ More recently, in a large longitudinal UK cohort study of 83,084 reproductive-age women with asthma aged 16-45 years with 456,803 person-years of followup, ${ }^{118}$ use of hormonal contraceptives was associated with a small protective effect on severe asthma exacerbations, with incidence rate ratios (IRRs) ranging from 0.92 to 0.96 . Taken together, from the available literature, hormonal contraceptives may be effective in controlling asthma symptoms in some PMA patients and reducing the risk of asthma exacerbations in reproductive-age women with asthma.

\section{Menopausal Hormone Therapy}

Several uncontrolled before-and-after studies evaluated the effects of MHT on clinical outcomes of asthma in menopausal women, but reported conflicting results. In 32 postmenopausal women with asthma using glucocorticoids, use of cyclical transdermal $17 \beta$-estradiol and medroxyprogesterone acetate improved lung function and reduced use of glucocorticoids and frequency of asthma exacerbations. ${ }^{119}$ By contrast, use of transdermal estradiol decreased PEF values and increased use of bronchodilators in 15 postmenopausal women with asthma. ${ }^{120}$ However, in another study of 20 postmenopausal women with asthma, ${ }^{121}$ no evidence was found that oral estrogen could affect $\mathrm{FEV}_{1}$, PEF or use of bronchodilators. Of note, due to potential limitations in uncontrolled before-and-after studies, ${ }^{122,123}$ these findings should be viewed with caution. To our best knowledge, there is only one longitudinal cohort study investigating the effects of MHT on clinical outcomes of asthma. In a national UK cohort study of 31,656 peri- and post-menopausal women with asthma aged 46-70 years with 366,678 person-years of follow-up, ${ }^{124}$ use of MHT and its subtypes (estrogen-alone therapy and estrogen plus progestin therapy) was associated with an increased risk of severe asthma exacerbations compared with non-use, with IRRs ranging from 1.07 to 1.28. Further, longer duration of use was associated with a higher risk of asthma exacerbations than shorter duration. ${ }^{124}$ Taken together, evidence on the impact of MHT use on clinical outcomes of asthma in menopausal women with asthma is still limited.

\section{Serum Levels of Sex Hormones}

In a small US cross-sectional study of 68 children with asthma aged 6-18 years, ${ }^{125}$ an elevated serum level of estradiol was associated with decreased $\mathrm{FEV}_{1}$ and FVC in girls, whereas an elevated serum level of dehydroepiandrosterone sulfate (DHEAS) was associated with increased $\mathrm{FEV}_{1}$ and $\mathrm{FVC}$ and deceased asthma symptoms in boys. Similarly, in another US cross-sectional study of 312 asthma patients aged 6-80 years, ${ }^{69}$ an elevated serum testosterone level was associated with increased $\mathrm{FEV}_{1}$ in both sexes. Further, in a UK cross-sectional study of 28,303 adults with asthma (14,056 women and 14,247 men) aged 40-69 years, ${ }^{68}$ an elevated serum level of free testosterone was associated with 
lower odds of wheezing symptoms (Q4 versus Q1: OR 0.78, 95\% CI 0.71-0.87) and asthma hospitalization (Q4 versus Q1: OR $0.73,95 \%$ CI $0.56-0.95$ ) in women, and with lower odds of wheezing symptoms (Q4 versus Q1: OR 0.86, 95\% CI 0.77-0.95) in men. Taken together, current evidence linking circulating sex hormones and clinical outcomes of asthma suggests that estradiol is associated with impaired lung function, while androgens including testosterone and DHEAS are associated with an improvement in lung function and asthma symptoms. However, the evidence is hampered by inherent limitations in the cross-sectional design.

\section{Mechanistic Evidence on Sex Hormones and Asthma Pathogenesis}

Asthma is a heterogenous disease characterized by airway inflammation, airway hyperresponsiveness (AHR), and airway remodeling. ${ }^{126}$ Multiple inflammatory pathways can mediate airway inflammation in asthma, mainly including eosinophilic type 2 high inflammation (allergic or non-allergic) and non-eosinophilic type 2 low inflammation (neutrophilic or pauci-granulocytic). ${ }^{126}$ Eosinophilic airway inflammation is mainly induced by increased production of type 2 cytokines (eg, interleukin [IL]-4, IL-5, IL-13) from T helper $2\left(\mathrm{~T}_{\mathrm{H}} 2\right)$ cells or group 2 innate lymphoid cells (ILC2s), which drive infiltration of eosinophils into the lung with or without increased immunoglobulin E (IgE) (Figure 1). ${ }^{127}$ Neutrophilic airway inflammation is primarily mediated by increased secretion of cytokines (eg, IL-17, IL-22, interferon- $\gamma$ [IFN- $\gamma$ ]) from $T_{H} 1$ cells, $T_{H} 17$ cells or ILC3s, which activate macrophages and promote release of neutrophilic chemokines (Figure 1). ${ }^{126,128}$ While eosinophilic airway inflammation is considered to be the most common among asthma patients, neutrophilic airway inflammation is present in many patients and associated with late-onset and more severe forms of

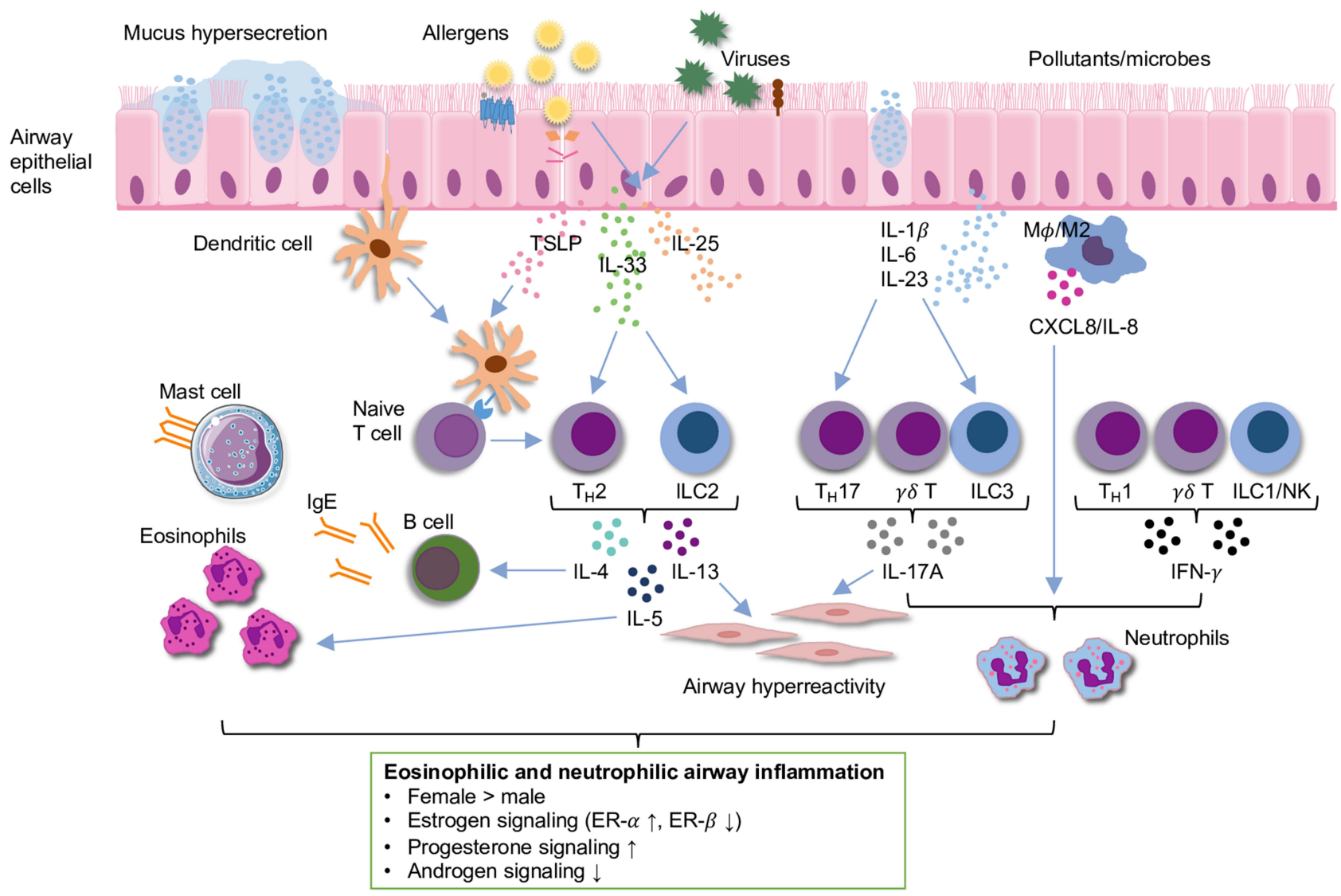

Figure I Schematic of eosinophilic and neutrophilic airway inflammation in asthma. Summary of sex differences and the role of sex hormone signaling in airway inflammation based on experimental evidence from human cells and animal studies are shown in the box below the schematic.

Notes: Modified from Yung JA, Fuseini H, Newcomb DC. Hormones, sex, and asthma. Ann Allergy Asthma Immunol. 2018;120(5):488-494, (C) 20I8 American College of Allergy, Asthma \& Immunology. Published by Elsevier Inc. All rights reserved. ${ }^{130}$

Abbreviations: CXCL8, C-X-C motif chemokine ligand 8; ER, estrogen receptor; IFN- $\gamma$; interferon- $\gamma$; IgE, immunoglobulin E; IL, interleukin; ILC, innate lymphoid cell; M $\varphi$, macrophage; NK, natural killer cell; $\mathrm{T}_{\mathrm{H}}$, $\mathrm{T}$ helper cell; TSLP, thymic stromal-derived lymphopoietin. 
asthma. ${ }^{127,129}$ Mounting mechanistic evidence suggests that sex hormones can act directly on airway and immune cells via different inflammatory pathways and play an important role in the pathogenesis of asthma, which has been reviewed extensively elsewhere. ${ }^{49,130-132}$ Here, we provide a brief discussion and a brief schematic (Figure 1) of some of the experimental evidence from human cells and animal studies.

\section{Gender-Related Differences}

In patients with moderate-to-severe asthma, women had a higher number of circulating ILC2s than men. ${ }^{133}$ In another study, women had a higher number of circulating microRNA (miR)-155-expressing ILC2s than men had, regardless of asthma diagnosis. ${ }^{134}$ Interestingly, ILCs and $\mathrm{T}_{\mathrm{H}}$ cells from women responded to various stimuli with higher miR-155 expression levels than male-derived cells, and miR-155 ${ }^{+} \mathrm{ILC} 2 \mathrm{~s}$ from women correlated with IL-5 levels in serum whereas male-derived cells did not. ${ }^{134} \mathrm{~T}_{\mathrm{H}} 17$ cells from women with severe asthma had increased IL-17A production compared to that from men with severe asthma. ${ }^{135}$ In mouse models of airway inflammation, ILC2s isolated from female mice had higher expression of IL-5 and IL-13 than that from male mice, ${ }^{136}$ and female mice had increased type 2 cytokines, IL$17 \mathrm{~A}$ protein expression, $\mathrm{T}_{\mathrm{H}} 2$ cells, eosinophils, neutrophils and macrophages in the lung, and serum total and antigenspecific IgE compared to male mice. ${ }^{133,137-144}$ These data suggest that there is a gender-related difference in airway inflammation, and sex hormones may play an important role in the pathogenesis of asthma.

\section{Estrogens and Progestogens}

In mouse models of allergic airway inflammation, ovariectomized female mice had decreased levels of eosinophils and type 2 cytokines in the lung and reduced AHR to methacholine, compared to sham-operated female mice. ${ }^{145,146}$ Estradiol treatment in ovariectomized mice partially restored AHR and levels of eosinophils and IL-5. ${ }^{145,147}$ However, it was also reported that ovariectomized mice had increased AHR compared to sham-operated mice, which was reversed after estradiol administration. ${ }^{148,149}$ Several studies used estrogen receptor (ER- $\alpha$ and ER- $\beta$ ) knockout mice to investigate the role of ERs in modulating airway inflammation, AHR or airway remodeling. ER- $\alpha$ knockout mice had lower levels of IL5, IL-13 and eosinophils in the lung, and reduced IL-33 release, AHR and remodeling, compared to wild-type mice, ${ }^{150,151}$ though in another study ER- $\alpha$ knockout mice had increased AHR. ${ }^{152}$ ER- $\beta$ knockout mice had increased AHR and remodeling compared to wild-type mice, ${ }^{150}$ and administration of an ER- $\beta$ agonist reduced AHR and remodeling. ${ }^{153}$ It seems that ER- $\alpha$ and ER- $\beta$ play an opposite role in the pathogenesis of allergic asthma. In addition, progesterone treatment increased levels of IL-4, IL-5 and eosinophils in the lung, serum levels of total IgE and AHR. ${ }^{154,155}$ On the other hand, $\mathrm{T}_{\mathrm{H}} 17$ cells from ovariectomized mice administered estradiol plus progesterone had increased IL-17A production and IL-23 receptor expression compared to that from those administered vehicle. ${ }^{135}$ Further, $\mathrm{T}_{\mathrm{H}} 17$ cells from ER- $\alpha$ deficient but not ER- $\beta$ deficient female mice had decreased proliferation, IL-17A production and IL-23 receptor expression, compared to that from wild-type female mice. ${ }^{156}$ Mucus production is a significant clinical problem in patients with severe phenotypes of asthma. In human airway epithelial cells, administration of estradiol increased mucin protein production including MUC5AC and MUC5B. ${ }^{157,158}$ Interestingly, in human non-asthmatic and asthmatic airway smooth muscle cells, prolonged exposure to an ER- $\alpha$ agonist led to increased levels of intracellular calcium, whereas ER- $\beta$ activation led to decreased levels, suggesting divergent regulation of airway contractility by ER- $\alpha$ versus ER- $\beta .{ }^{159}$ Taken together, these data suggest that estrogen signaling possibly through ER- $\alpha$ as well as progestogen signaling may enhance eosinophilic and neutrophilic airway inflammation, mucus production, AHR or airway remodeling.

\section{Androgens}

Sham-operated male mice and gonadectomized male mice administered $5 \alpha$-dihydrotestosterone ( $5 \alpha$-DHT, a hormone downstream of testosterone) had decreased lung ILC2s numbers compared to gonadectomized male mice. ${ }^{133}$ In in vitro studies, IL-5 and IL-13 protein expression was decreased in ILC2s from sham-operated male mice and gonadectomized male mice administered $5 \alpha$-DHT compared to ILC2s from gonadectomized male mice. ${ }^{133}$ In mouse models of airway inflammation, sham-operated male mice had decreased $\mathrm{T}_{\mathrm{H}} 2$ cells, $\mathrm{T}_{\mathrm{H}} 17$ cells, eosinophils and neutrophils in the lung, AHR and total serum IgE compared to gonadectomized male mice. ${ }^{133,142}$ Further, dehydroepiandrosterone (DHEA)- 
treated mice had reduced AHR, and lower levels of eosinophils, IL-4, IL-5 and IFN- $\gamma$ in the lung and serum total and antigen-specific IgE, compared to non-DHEA treated mice. ${ }^{160,161}$ In addition, mouse models using a mutated androgen receptor showed that androgen receptor signaling downregulated $\mathrm{T}_{\mathrm{H}} 2$ cells-mediated, ILC2s-mediated and IL-17Amediated airway inflammation. ${ }^{133,142}$ Taken together, these data suggest that androgens may reduce eosinophilic and neutrophilic airway inflammation and AHR.

\section{Clinical Implications}

According to the sex hormone hypotheses, ${ }^{48}$ in reproductive-age women suppression of ovarian secretion of estrogens and progestogens (eg, use of hormonal contraceptives) during the menstrual cycle may decrease the risk of developing asthma and improve clinical outcomes, whereas in menopausal women supplementation of estrogens and progestogens (eg, use of MHT) may increase the risk and worsen clinical outcomes. Although mixed epidemiological evidence existed for the effects of hormonal contraceptives and MHT on asthma risk in women, most studies showed that use of hormonal contraceptives was associated with a decreased risk of developing asthma, while use of MHT was associated with an increased risk. Among reproductive-age women with asthma, most case reports suggested beneficial effects of hormonal contraceptives in alleviating PMA, and several longitudinal cohort studies consistently reported that use of hormonal contraceptives was associated with a decreased risk of having asthma symptoms or exacerbations. Evidence on MHT in menopausal women with asthma is limited and mainly comes from the large national UK cohort study, ${ }^{124}$ which showed that use of MHT was associated with an increased risk of asthma exacerbations. Currently, there are no special guidelines on the prescription of hormonal contraceptives or MHT to women at risk of developing asthma or with asthma. Whist further studies are being needed to strengthen the evidence, the possible asthma-related benefits and risks of hormonal contraceptives and MHT should be taken into account in the context of their widely accepted benefits and harms.

In addition, the sex hormone hypotheses suggest that androgens may decrease the risk of developing asthma and improve clinical outcomes. ${ }^{48,49}$ However, evidence in this regard primarily comes from cross-sectional analyses of serum testosterone levels in women or men with or without asthma. In a multi-center, randomized, double-blind, placebocontrolled trial of 281 moderate-to-severe asthma patients aged 18-70 years, ${ }^{162}$ administration of nebulized DHEAS (70 mg once daily) for six weeks improved asthma control scores compared to placebo, in addition to low-dose inhaled corticosteroid (fluticasone) and long-acting $\beta_{2}$-agonist (salmeterol). More evidence on androgens and asthma is needed to inform practice.

\section{Future Perspectives}

From the available observational studies on sex hormones and asthma onset in women, robust consistent evidence exists only for the role of puberty. Evidence on menstruation and pregnancy is quite limited and comes only from crosssectional studies. Further studies with a longitudinal design are required to allow temporality to be assessed. Studies on menopause have reported contradictory results. MR studies using genetic variants for menopause will hopefully provide more insights into this controversy. There is mixed epidemiological evidence for the effects of hormonal contraceptives and MHT on asthma risk. So far, no randomized clinical trial exists on the topic. More robustly designed longitudinal cohort studies taking into account their subtypes, dosages, routes of administration and durations of use across different populations are warranted to provide more clarity. Accounting for these details will not only help to resolve the inconsistencies in observational studies but also provide the basis for potential future clinical trials assessing the efficacy of hormonal contraceptives in primary prevention of asthma in women.

Further longitudinal studies that track women with asthma in a life-course perspective that includes key hormonal transition points, such as puberty, menstruation, pregnancy and menopause, are warranted. Identifying the specific role of each of these hormonal events as well as other associated risk factors will help to predict the course of asthma and optimize care for women with asthma during the various reproductive phases of life. There is increasing epidemiological evidence that use of hormonal contraceptives is associated with a decreased risk of experiencing asthma symptoms or exacerbations among reproductive-age women with asthma. Therapeutic effects of hormonal contraceptives in PMA have also been noted in several case reports. So far, however, there have been no clinical trials investigating the efficacy of hormonal contraceptives in asthma control. In light of the potential beneficial role of hormonal contraceptives as well as 
the high prevalence of PMA, well-designed randomized clinical trials of use of hormonal contraceptives in women with asthma, especially in those with PMA, should now be performed to assess whether hormonal contraceptives have any therapeutic implications for asthma. This will need to take into account the potential varying effects of hormonal contraceptives by subtype, dosage, route of administration and duration of use on various phenotypes of asthma, thus generating evidence for more individualized asthma management. In addition, DHEAS intake has been suggested to improve short-term asthma symptoms in a randomized clinical trial. ${ }^{162}$ Further trials of DHEAS with a longer follow-up period across different asthma phenotypes are required to replicate the findings. Lastly, additional longitudinal cohort studies of MHT use in menopausal women with asthma are also warranted.

There are an increasing number of studies that directly measure the circulating levels of sex hormones in relation to asthma. Unfortunately, their ability to infer causality is largely hampered by the inherent limitations in their crosssectional design. Whenever possible, future studies of serum levels of sex hormones with a longitudinal design should be encouraged, and specific asthma-related outcome measures, such as incidence, remission, exacerbation and mortality, should be used to disentangle the potential complex role of sex hormones during different phases of asthma. There is also a need to understand the role of sex hormones in the underlying immunopathology and the endotypes of different asthma phenotypes, an aspect largely neglected in previous studies.

In patients with moderate or severe asthma, add-on treatment with biologic agents may be considered. ${ }^{1}$ Currently available biologics are mostly targeted towards type 2 high inflammation, such as omalizumab (anti-IgE), dupilumab (anti-IL-4 receptor $\alpha$ ), mepolizumab (anti-IL-5) and benralizumab (anti-IL-5 receptor $\alpha$ ), which is generally less common in women than in men. ${ }^{1,127,163}$ However, gender differences in the efficacy of the biologics in severe asthma have not been extensively investigated. ${ }^{163,164}$ Some randomized trials explored gender differences in responsiveness to these biologics and did not find differential responses between women and men. ${ }^{165-171}$ To our knowledge, no human studies have looked at the effects of these biologics on hormonal activity. Future studies are needed to investigate how the biologics could affect hormonal activity as well as whether clinically important differences by gender exist in the efficacy of the biologics in asthma treatment.

\section{Conclusions}

The phenomenon that a gender-related switch in asthma development and clinical morbidity coincides with changes in sex hormones has led to the hypothesis that sex hormones may play an important role in asthma pathogenesis and clinical outcomes. Indeed, some women experience changes in asthma symptoms during various reproductive phases of life such as puberty, menstruation and pregnancy. There is increasing epidemiological or clinical evidence showing that suppression of ovarian secretion of female sex hormones (eg, use of hormonal contraceptives) may decrease asthma risk and improve clinical outcomes of asthma, whereas supplementation of female sex hormones (eg, use of MHT) may increase the risk and worsen asthma outcomes.

Epidemiological evidence regarding androgens is limited and mainly comes from cross-sectional studies of serum testosterone levels. Furthermore, mechanistic studies have revealed that estrogen signaling (possibly through ER- $\alpha$ ) as well as progestogen signaling promotes and androgen signaling attenuates eosinophilic and neutrophilic airway inflammation. Collectively, evidence is accumulating that sex hormones may modulate the pathogenesis and clinical manifestations of asthma. Further well-designed randomized trials assessing the potential preventive or therapeutic effects of hormonal contraceptives on asthma in women will help to advance the evidence to inform future practice guidelines. The mechanisms underlying the role of sex hormones in asthma are complex, and our understanding is not yet complete. Additional mechanistic studies elucidating sex hormone signaling pathways and their interactions involved in the pathogenesis and clinical manifestations of asthma will help to identify potential sex hormone-driven asthma endotypes and novel therapeutic targets, providing the basis for a more personalized asthma management strategy.

\section{Abbreviations}

AHR, airway hyperresponsiveness; CI, confidence interval; DHEA, dehydroepiandrosterone; DHEAS, dehydroepiandrosterone sulfate; ER, estrogen receptor; $\mathrm{FEV}_{1}$, forced expiratory volume in one second; $5 \alpha$-DHT, $5 \alpha$-dihydrotestosterone; FVC, forced vital capacity; HR, hazard ratio; IFN- $\gamma$, interferon- $\gamma$; IgE, immunoglobulin E; IL, interleukin; ILC2s, 
group 2 innate lymphoid cells; ILC3s, group 3 innate lymphoid cells; IRR, incidence rate ratio; MHT, menopausal hormone therapy; miR, microRNA; MR, Mendelian randomization; OR, odds ratio; PEF, peak expiratory flow; PMA, perimenstrual asthma; Q1, the lowest quartile; Q4, the highest quartile; SHBG, sex hormone-binding globulin; TAHS, Tasmanian Longitudinal Health Study; $\mathrm{T}_{\mathrm{H}} 1$ cells, $\mathrm{T}$ helper 1 cells; $\mathrm{T}_{\mathrm{H}} 2$ cells, $\mathrm{T}$ helper 2 cells; $\mathrm{T}_{\mathrm{H}} 17$ cells, $\mathrm{T}$ helper 17 cells.

\section{Funding}

This work was supported by grants from Herman Krefting Foundation for Asthma and Allergy research, The Swedish Research Council (2017-02302, 2019-00247), The Swedish Heart and Lung Foundation (202000619), and the ALF/LUA research grant from Sahlgrenska University Hospital (ALFGBG-822751). BN acknowledges the support of Knut and Alice Wallenberg Foundation, the Wallenberg Centre for Molecular and Translational Medicine. The funders had no role in study design, data collection and analysis, decision to publish, or preparation of the manuscript.

\section{Disclosure}

Professor Hannu Kankaanranta reports personal fees, non-financial support from AstraZeneca, personal fees from Boehringer-Ingelheim, personal fees from Chiesi, personal fees from GlaxoSmithKline, personal fees, non-financial support from Orion Pharma, personal fees from MSD, personal fees from Novartis, personal fees from SanofiGenzyme, outside the submitted work. The authors report no other conflicts of interest in this work.

\section{References}

1. Global Initiative for Asthma. Global strategy for asthma management and prevention; 2021. Available from: www.ginasthma.org. Accessed September 27, 2021.

2. Murray CJ, Aravkin AY, Zheng P, et al.Global burden of 369 diseases and injuries in 204 countries and territories, 1990-2019: a systematic analysis for the Global Burden of Disease Study 2019. Lancet. 2020;396(10258):1204-1222. doi:10.1016/S0140-6736(20)30925-9

3. Dodge RR, Burrows B. The prevalence and incidence of asthma and asthma-like symptoms in a general population sample. Am Rev Respir Dis. 1980;122(4):567-575. doi:10.1164/arrd.1980.122.4.567

4. Anderson HR, Pottier AC, Strachan DP. Asthma from birth to age 23: incidence and relation to prior and concurrent atopic disease. Thorax. 1992;47(7):537-542. doi:10.1136/thx.47.7.537

5. Yunginger JW, Reed CE, O'Connell EJ, Melton LJ, O'Fallon WM, Silverstein MD. A community-based study of the epidemiology of asthma. Incidence rates, 1964-1983. Am Rev Respir Dis. 1992;146(4):888-894. doi:10.1164/ajrccm/146.4.888

6. Sears MR, Burrows B, Flannery EM, Herbison GP, Holdaway MD. Atopy in childhood. I. Gender and allergen related risks for development of hay fever and asthma. Clin Exp Allergy. 1993;23(11):941-948. doi:10.1111/j.1365-2222.1993.tb00279.x

7. Harju T, Keistinen T, Tuuponen T, Kivelä SL. Hospital admissions of asthmatics by age and sex. Allergy. 1996;51(10):693-696.

8. Ciccone G, Camarlengo A, Bugiani M, et al.Asthma and respiratory symptoms in 6-7 yr old Italian children: gender, latitude, urbanization and socioeconomic factors. SIDRIA (Italian Studies on Respiratory Disorders in Childhood and the Environment). Eur Respir J. 1997;10(8):17801786. doi:10.1183/09031936.97.10081780

9. de Marco R, Locatelli F, Sunyer J, Burney P. Differences in incidence of reported asthma related to age in men and women. A retrospective analysis of the data of the European Respiratory Health Survey. Am J Respir Crit Care Med. 2000;162(1):68-74. doi:10.1164/ ajrccm.162.1.9907008

10. de Marco R, Locatelli F, Cerveri I, Bugiani M, Marinoni A, Giammanco G. Incidence and remission of asthma: a retrospective study on the natural history of asthma in Italy. J Allergy Clin Immunol. 2002;110(2):228-235. doi:10.1067/mai.2002.125600

11. Chen Y, Stewart P, Johansen H, McRae L, Taylor G. Sex difference in hospitalization due to asthma in relation to age. J Clin Epidemiol. 2003;56(2):180-187. doi:10.1016/S0895-4356(02)00593-0

12. Schatz M, Camargo CA. The relationship of sex to asthma prevalence, health care utilization, and medications in a large managed care organization. Ann Allergy Asthma Immunol. 2003;91(6):553-558. doi:10.1016/S1081-1206(10)61533-5

13. Debley JS, Redding GJ, Critchlow CW. Impact of adolescence and gender on asthma hospitalization: a population-based birth cohort study. Pediatr Pulmonol. 2004;38(6):443-450. doi:10.1002/ppul.20108

14. Almqvist C, Worm M, Leynaert B. Impact of gender on asthma in childhood and adolescence: a GA2LEN review. Allergy. 2008;63(1):47-57. doi:10.1111/j.1398-9995.2007.01524.x

15. Vink NM, Postma DS, Schouten JP, Rosmalen JG, Boezen HM. Gender differences in asthma development and remission during transition through puberty: the TRacking Adolescents' Individual Lives Survey (TRAILS) study. J Allergy Clin Immunol. 2010;126(3):498-504. doi:10.1016/j.jaci.2010.06.018

16. Gershon AS, Guan J, Wang C, To T. Trends in asthma prevalence and incidence in Ontario, Canada, 1996-2005: a population study. Am J Epidemiol. 2010;172(6):728-736. doi:10.1093/aje/kwq189

17. Kankaanranta H, Tuomisto LE, Ilmarinen P. Age-specific incidence of new asthma diagnoses in Finland. J Allergy Clin Immunol Pract. 2017;5 (1):189-191. doi:10.1016/j.jaip.2016.08.015

18. Honkamäki J, Hisinger-Mölkänen H, Ilmarinen P, et al. Age- and gender-specific incidence of new asthma diagnosis from childhood to late adulthood. Respir Med. 2019;154:56-62. doi:10.1016/j.rmed.2019.06.003 
19. Centers for Disease Control and Prevention. Asthma: data, statistics, and surveillance; 2019. Available from: https://www.cdc.gov/asthma/most recent_national_asthma_data.htm. Accessed September 27, 2021.

20. Larsson L. Incidence of asthma in Swedish teenagers: relation to sex and smoking habits. Thorax. 1995;50(3):260-264. doi:10.1136/ thx.50.3.260

21. Torén K, Hermansson BA. Incidence rate of adult-onset asthma in relation to age, sex, atopy and smoking: a Swedish population-based study of 15813 adults. Int J Tuberc Lung Dis. 1999;3(3):192-197.

22. Lundbäck B, Rönmark E, Jönsson E, Larsson K, Sandström T. Incidence of physician-diagnosed asthma in adults-a real incidence or a result of increased awareness? Report from the Obstructive Lung Disease in Northern Sweden Studies. Respir Med. 2001;95(8):685-692. doi:10.1053/ rmed.2001.1126

23. Thomsen SF, Ulrik CS, Kyvik KO, et al. The incidence of asthma in young adults. Chest. 2005;127(6):1928-1934. doi:10.1378/ chest.127.6.1928

24. Eagan TM, Brøgger JC, Eide GE, Bakke PS. The incidence of adult asthma: a review. Int J Tuberc Lung Dis. 2005;9(6):603-612.

25. Torén K, Ekerljung L, Kim JL, et al. Adult-onset asthma in west Sweden-incidence, sex differences and impact of occupational exposures. Respir Med. 2011;105(11):1622-1628. doi:10.1016/j.rmed.2011.06.003

26. Leynaert B, Sunyer J, Garcia-Esteban R, et al. Gender differences in prevalence, diagnosis and incidence of allergic and non-allergic asthma: a population-based cohort. Thorax. 2012;67(7):625-631. doi:10.1136/thoraxjnl-2011-201249

27. Hansen S, Probst-Hensch N, Keidel D, et al. Gender differences in adult-onset asthma: results from the Swiss SAPALDIA cohort study. Eur Respir J. 2015;46(4):1011-1020. doi:10.1183/13993003.02278-2014

28. de Marco R, Locatelli F, Cazzoletti L, Bugianio M, Carosso A, Marinoni A. Incidence of asthma and mortality in a cohort of young adults: a 7year prospective study. Respir Res. 2005;6(1):95. doi:10.1186/1465-9921-6-95

29. Borna E, Nwaru BI, Bjerg A, et al. Changes in the prevalence of asthma and respiratory symptoms in western Sweden between 2008 and 2016. Allergy. 2019;74(9):1703-1715. doi:10.1111/all.13840

30. Pallasaho P, Juusela M, Lindqvist A, Sovijärvi A, Lundbäck B, Rönmark E. Allergic rhinoconjunctivitis doubles the risk for incident asthmaresults from a population study in Helsinki, Finland. Respir Med. 2011;105(10):1449-1456. doi:10.1016/j.rmed.2011.04.013

31. Basagaña X, Sunyer J, Zock JP, et al. Incidence of asthma and its determinants among adults in Spain. Am J Respir Crit Care Med. 2001;164 (7):1133-1137. doi:10.1164/ajrccm.164.7.2012143

32. Prescott E, Lange P, Vestbo J. Effect of gender on hospital admissions for asthma and prevalence of self-reported asthma: a prospective study based on a sample of the general population. Copenhagen City Heart Study Group. Thorax. 1997;52(3):287-289. doi:10.1136/thx.52.3.287

33. Australian Institute of Health and Welfare. Asthma: impact; 2020. Available from: https:/www.aihw.gov.au/reports/chronic-respiratory-condi tions/asthma/contents/deaths. Accessed September 27, 2021.

34. Miranda C, Busacker A, Balzar S, Trudeau J, Wenzel SE. Distinguishing severe asthma phenotypes: role of age at onset and eosinophilic inflammation. J Allergy Clin Immunol. 2004;113(1):101-108. doi:10.1016/j.jaci.2003.10.041

35. de Nijs SB, Venekamp LN, Bel EH. Adult-onset asthma: is it really different? Eur Respir Rev. 2013;22(127):44-52. doi:10.1183/ 09059180.00007112

36. Wenzel SE. Asthma phenotypes: the evolution from clinical to molecular approaches. Nat Med. 2012;18(5):716-725. doi:10.1038/nm.2678

37. Pakkasela J, Ilmarinen P, Honkamäki J, et al. Age-specific incidence of allergic and non-allergic asthma. BMC Pulm Med. $2020 ; 20(1): 9$. doi:10.1186/s12890-019-1040-2

38. Ten Brinke A, Zwinderman AH, Sterk PJ, Rabe KF, Bel EH. Factors associated with persistent airflow limitation in severe asthma. Am J Respir Crit Care Med. 2001;164(5):744-748. doi:10.1164/ajrccm.164.5.2011026

39. Tan DJ, Walters EH, Perret JL, et al. Clinical and functional differences between early-onset and late-onset adult asthma: a population-based Tasmanian Longitudinal Health Study. Thorax. 2016;71(11):981-987. doi:10.1136/thoraxjnl-2015-208183

40. Honkamäki J, Piirilä P, Hisinger-Mölkänen H, et al. Asthma remission by age at diagnosis and gender in a population-based study. $J$ Allergy Clin Immunol Pract. 2021;9(5):1950-1959. doi:10.1016/j.jaip.2020.12.015

41. Rönmark E, Lindberg A, Watson L, Lundbäck B. Outcome and severity of adult onset asthma-report from the obstructive lung disease in northern Sweden studies (OLIN). Respir Med. 2007;101(11):2370-2377. doi:10.1016/j.rmed.2007.06.011

42. Tuomisto LE, Ilmarinen P, Niemelä O, Haanpää J, Kankaanranta T, Kankaanranta H. A 12-year prognosis of adult-onset asthma: Seinäjoki Adult Asthma Study. Respir Med. 2016;117:223-229. doi:10.1016/j.rmed.2016.06.017

43. Westerhof GA, Coumou H, de Nijs SB, Weersink EJ, Bel EH. Clinical predictors of remission and persistence of adult-onset asthma. J Allergy Clin Immunol. 2018;141(1):104-109. doi:10.1016/j.jaci.2017.03.034

44. Almqvist L, Rönmark E, Stridsman C, et al. Remission of adult-onset asthma is rare: a 15-year follow-up study. ERJ Open Res. 2020;6 (4):00620-2020. doi:10.1183/23120541.00620-2020

45. Sözener Z, Aydın Ö, Mungan D, Misırlıgil Z. Prognosis of adult asthma: a 7-year follow-up study. Ann Allergy Asthma Immunol. 2015;114 (5):370-373. doi:10.1016/j.anai.2015.02.010

46. Sood A, Qualls C, Schuyler M, et al. Adult-onset asthma becomes the dominant phenotype among women by age 40 years. the longitudinal CARDIA study. Ann Am Thorac Soc. 2013;10(3):188-197. doi:10.1513/AnnalsATS.201212-115OC

47. Melgert BN, Ray A, Hylkema MN, Timens W, Postma DS. Are there reasons why adult asthma is more common in females? Curr Allergy Asthma Rep. 2007;7(2):143-150. doi:10.1007/s11882-007-0012-4

48. Zhang GQ, Bossios A, Rådinger M, Nwaru BI. Sex steroid hormones and asthma in women: state-of-the-art and future research perspectives. Expert Rev Respir Med. 2020;14(6):543-545. doi:10.1080/17476348.2020.1741351

49. Laffont S, Blanquart E, Guéry JC. Sex differences in asthma: a key role of androgen-signaling in group 2 innate lymphoid cells. Front Immunol. 2017;8:1069. doi:10.3389/fimmu.2017.01069

50. Sheikh A, Mukherjee M. We need a robust evidence base to unravel the relationship between sex hormones and asthma. Thorax. 2020;75 (10):826-827. doi:10.1136/thoraxjnl-2020-215566

51. McCleary N, Nwaru BI, Nurmatov UB, Critchley H, Sheikh A. Endogenous and exogenous sex steroid hormones in asthma and allergy in females: a systematic review and meta-analysis. J Allergy Clin Immunol. 2018;141(4):1510-1513. doi:10.1016/j.jaci.2017.11.034 
52. Minelli C, van der Plaat DA, Leynaert B, et al. Age at puberty and risk of asthma: a Mendelian randomisation study. PLoS Med. 2018;15(8): e1002634. doi:10.1371/journal.pmed.1002634

53. Chen YC, Fan HY, Yang C, Lee YL. Early pubertal maturation and risk of childhood asthma: a Mendelian randomization and longitudinal study. Allergy. 2020;75(4):892-900. doi:10.1111/all.14009

54. Sheehan NA, Didelez V, Burton PR, Tobin MD. Mendelian randomisation and causal inference in observational epidemiology. PLoS Med. 2008;5(8):e177. doi:10.1371/journal.pmed.0050177

55. Mendle J, Turkheimer E, Emery RE. Detrimental psychological outcomes associated with early pubertal timing in adolescent girls. Dev Rev. 2007;27(2):151-171. doi:10.1016/j.dr.2006.11.001

56. Jenkins MA, Dharmage SC, Flander LB, et al. Parity and decreased use of oral contraceptives as predictors of asthma in young women. Clin Exp Allergy. 2006;36(5):609-613. doi:10.1111/j.1365-2222.2006.02475.x

57. Matheson MC, Burgess JA, Lau MY, et al. Hormonal contraception increases risk of asthma among obese but decreases it among nonobese subjects: a prospective, population-based cohort study. ERJ Open Res. 2015;1(2):00026-2015. doi:10.1183/23120541.00026-2015

58. Forastiere F, Sunyer J, Farchi S, et al. Number of offspring and maternal allergy. Allergy. 2005;60(4):510-514. doi:10.1111/j.13989995.2005.00736.x

59. Troisi RJ, Speizer FE, Willett WC, Trichopoulos D, Rosner B. Menopause, postmenopausal estrogen preparations, and the risk of adult-onset asthma. A prospective cohort study. Am J Respir Crit Care Med. 1995;152(4 Pt 1):1183-1188. doi:10.1164/ajrccm.152.4.7551368

60. Triebner K, Johannessen A, Puggini L, et al. Menopause as a predictor of new-onset asthma: a longitudinal Northern European population study. J Allergy Clin Immunol. 2016;137(1):50-57. doi:10.1016/j.jaci.2015.08.019

61. Matulonga-Diakiese B, Courbon D, Fournier A, et al. Risk of asthma onset after natural and surgical menopause: results from the French E3N cohort. Maturitas. 2018;118:44-50. doi:10.1016/j.maturitas.2018.10.006

62. Shah SA, Tibble H, Pillinger R, et al. Hormone replacement therapy and asthma onset in menopausal women: national cohort study. $J$ Allergy Clin Immunol. 2021;147(5):1662-1670. doi:10.1016/j.jaci.2020.11.024

63. Wei J, Gerlich J, Genuneit J, et al. Hormonal factors and incident asthma and allergic rhinitis during puberty in girls. Ann Allergy Asthma Immunol. 2015;115(1):21-27. doi:10.1016/j.anai.2015.04.019

64. Nwaru BI, Pillinger R, Tibble H, et al. Hormonal contraceptives and onset of asthma in reproductive-age women: population-based cohort study. J Allergy Clin Immunol. 2020;146(2):438-446. doi:10.1016/j.jaci.2020.02.027

65. Zhang GQ, Chen JL, Luo Y, et al. Menopausal hormone therapy and women's health: an umbrella review. PLoS Med. $2021 ; 18(8)$ :e1003731. doi:10.1371/journal.pmed.1003731

66. Hansen ESH, Aasbjerg K, Moeller AL, Gade EJ, Torp-Pedersen C, Backer V. Hormone replacement therapy and development of new asthma. Chest. 2021;160(1):45-52. doi:10.1016/j.chest.2021.01.054

67. Han YY, Forno E, Celedón JC. Sex steroid hormones and asthma in a nationwide study of U.S. adults. Am J Respir Crit Care Med. 2020;201 (2):158-166. doi:10.1164/rccm.201905-0996OC

68. Han YY, Yan Q, Yang G, Chen W, Forno E, Celedon JC. Serum free testosterone and asthma, asthma hospitalisations and lung function in British adults. Thorax. 2020;75(10):849-854. doi:10.1136/thoraxjnl-2020-214875

69. Bulkhi AA, Shepard KV, Casale TB, Cardet JC. Elevated testosterone is associated with decreased likelihood of current asthma regardless of sex. J Allergy Clin Immunol Pract. 2020;8(9):3029-3035. doi:10.1016/j.jaip.2020.05.022

70. Arathimos R, Granell R, Haycock P, et al. Genetic and observational evidence supports a causal role of sex hormones on the development of asthma. Thorax. 2019;74(7):633-642. doi:10.1136/thoraxjnl-2018-212207

71. Fu L, Freishtat RJ, Gordish-Dressman H, et al. Natural progression of childhood asthma symptoms and strong influence of sex and puberty. Ann Am Thorac Soc. 2014;11(6):939-944. doi:10.1513/AnnalsATS.201402-084OC

72. Vrieze A, Postma DS, Kerstjens HA. Perimenstrual asthma: a syndrome without known cause or cure. J Allergy Clin Immunol. 2003;112 (2):271-282. doi:10.1067/mai.2003.1676

73. Suzuki K, Hasegawa T, Sakagami T, et al. Analysis of perimenstrual asthma based on questionnaire surveys in Japan. Allergol Int. 2007;56 (3):249-255. doi:10.2332/allergolint.O-06-475

74. Rao CK, Moore CG, Bleecker E, et al. Characteristics of perimenstrual asthma and its relation to asthma severity and control: data from the Severe Asthma Research Program. Chest. 2013;143(4):984-992. doi:10.1378/chest.12-0973

75. Eid RC, Palumbo ML, Cahill KN. Perimenstrual asthma in aspirin-exacerbated respiratory disease. J Allergy Clin Immunol Pract. 2020;8 (2):573-578. doi:10.1016/j.jaip.2019.08.054

76. Eliasson O, Scherzer HH, DeGraff AC. Morbidity in asthma in relation to the menstrual cycle. J Allergy Clin Immunol. 1986;77(1 Pt 1):87-94. doi:10.1016/0091-6749(86)90328-3

77. Agarwal AK, Shah A. Menstrual-linked asthma. J Asthma. 1997;34(6):539-545. doi:10.3109/02770909709055398

78. Shames RS, Heilbron DC, Janson SL, Kishiyama JL, Au DS, Adelman DC. Clinical differences among women with and without self-reported perimenstrual asthma. Ann Allergy Asthma Immunol. 1998;81(1):65-72. doi:10.1016/S1081-1206(10)63111-0

79. Thornton J, Lewis J, Lebrun CM, Licskai CJ. Clinical characteristics of women with menstrual-linked asthma. Respir Med. 2012;106(9):12361243. doi:10.1016/j.rmed.2012.05.003

80. Lenoir RJ. Severe acute asthma and the menstrual cycle. Anaesthesia. 1987;42(12):1287-1290. doi:10.1111/j.1365-2044.1987.tb05275.x

81. Beynon HL, Garbett ND, Barnes PJ. Severe premenstrual exacerbations of asthma: effect of intramuscular progesterone. Lancet. 1988;332 (8607):370-372. doi:10.1016/S0140-6736(88)92837-1

82. Kisiel M, Berglund C, Janson C, et al. Quality of life and asthma control related to hormonal transitions in women's lives. J Asthma. 2021;1-9. doi:10.1080/02770903.2021.1963768

83. Gluck JC, Gluck P. The effects of pregnancy on asthma: a prospective study. Ann Allergy. 1976;37(3):164-168.

84. Schatz M, Harden K, Forsythe A, et al. The course of asthma during pregnancy, post partum, and with successive pregnancies: a prospective analysis. J Allergy Clin Immunol. 1988;81(3):509-517. doi:10.1016/0091-6749(88)90187-X

85. Schatz M. Interrelationships between asthma and pregnancy: a literature review. J Allergy Clin Immunol. 1999;103(2 Pt 2):S330-S336. doi:10.1016/S0091-6749(99)70258-7 
86. Schatz M, Dombrowski MP, Wise R, et al. Asthma morbidity during pregnancy can be predicted by severity classification. $J$ Allergy Clin Immunol. 2003;112(2):283-288. doi:10.1067/mai.2003.1516

87. Murphy VE, Gibson P, Talbot PI, Clifton VL. Severe asthma exacerbations during pregnancy. Obstet Gynecol. 2005;106(5 Pt 1):1046-1054. doi:10.1097/01.AOG.0000185281.21716.02

88. Belanger K, Hellenbrand ME, Holford TR, Bracken M. Effect of pregnancy on maternal asthma symptoms and medication use. Obstet Gynecol. 2010;115(3):559-567. doi:10.1097/AOG.0b013e3181d06945

89. Ali Z, Nilas L, Ulrik CS. Determinants of low risk of asthma exacerbation during pregnancy. Clin Exp Allergy. 2018;48(1):23-28. doi:10.1111/ cea. 13033

90. Bokern M, Robijn A, Jensen ME, et al. Factors associated with asthma exacerbations during pregnancy. J Allergy Clin Immunol Pract. 2021;9:4343-4352.e4. doi:10.1016/j.jaip.2021.07.055

91. Gluck JC, Gluck PA. The effect of pregnancy on the course of asthma. Immunol Allergy Clin North Am. 2006;26(1):63-80. doi:10.1016/j. iac.2005.10.008

92. Gelber M, Sidi Y, Gassner S, et al. Uncontrollable life-threatening status asthmaticus-an indicator for termination of pregnancy by cesarean section. Respiration. 1984;46(3):320-322. doi:10.1159/000194705

93. Shanies HM, Venkataraman MT, Peter T. Reversal of intractable acute severe asthma by first-trimester termination of pregnancy. $J$ Asthma. 1997;34(2):169-172. doi:10.3109/02770909709075662

94. Murphy VE, Gibson PG, Smith R, Clifton VL. Asthma during pregnancy: mechanisms and treatment implications. Eur Respir J. 2005;25 (4):731-750. doi:10.1183/09031936.05.00085704

95. Meulenberg PM, Hofman JA. Maternal testosterone and fetal sex. J Steroid Biochem Mol Biol. 1991;39(1):51-54. doi:10.1016/0960-0760(91) 90012-T

96. Clifton VL, Murphy VE. Maternal asthma as a model for examining fetal sex-specific effects on maternal physiology and placental mechanisms that regulate human fetal growth. Placenta. 2004;25(Suppl A):S45-S52. doi:10.1016/j.placenta.2004.01.004

97. Murphy VE, Gibson PG, Giles WB, et al. Maternal asthma is associated with reduced female fetal growth. Am J Respir Crit Care Med. 2003;168(11):1317-1323. doi:10.1164/rccm.200303-374OC

98. Mitchell AM, Palettas M, Christian LM. Fetal sex is associated with maternal stimulated cytokine production, but not serum cytokine levels, in human pregnancy. Brain Behav Immun. 2017;60:32-37. doi:10.1016/j.bbi.2016.06.015

99. Scott NM, Hodyl NA, Murphy VE, et al. Placental cytokine expression covaries with maternal asthma severity and fetal sex. $J$ Immunol. 2009;182(3):1411-1420. doi:10.4049/jimmunol.182.3.1411

100. Kwon HL, Belanger K, Holford TR, Bracken MB. Effect of fetal sex on airway lability in pregnant women with asthma. Am J Epidemiol. 2006;163(3):217-221. doi:10.1093/aje/kwj032

101. Dodds L, Armson BA, Alexander S. Use of asthma drugs is less among women pregnant with boys rather than girls. BMJ. 1999;318 (7189):1011. doi:10.1136/bmj.318.7189.1011

102. Beecroft N, Cochrane GM, Milburn HJ. Effect of sex of fetus on asthma during pregnancy: blind prospective study. BMJ. 1998;317(7162):856857. doi:10.1136/bmj.317.7162.856

103. Bakhireva LN, Schatz M, Jones KL, et al. Fetal sex and maternal asthma control in pregnancy. $J$ Asthma. 2008;45(5):403-407. doi:10.1080/ 02770900801971826

104. Kircher S, Schatz M, Long L. Variables affecting asthma course during pregnancy. Ann Allergy Asthma Immunol. 2002;89(5):463-466. doi:10.1016/S1081-1206(10)62082-0

105. Baibergenova A, Thabane L, Akhtar-Danesh N, Levine M, Gafni A. Is fetal gender associated with emergency department visits for asthma during pregnancy? J Asthma. 2006;43(4):293-299. doi:10.1080/02770900600622984

106. Firoozi F, Ducharme FM, Lemière C, et al. Effect of fetal gender on maternal asthma exacerbations in pregnant asthmatic women. Respir Med. 2009;103(1):144-151. doi:10.1016/j.rmed.2008.07.013

107. Campbell B, Davis SR, Abramson MJ, et al. Menopause, lung function and obstructive lung disease outcomes: a systematic review. Climacteric. 2018;21(1):3-12. doi:10.1080/13697137.2017.1392504

108. Tang R, Fraser A, Magnus MC. Female reproductive history in relation to chronic obstructive pulmonary disease and lung function in UK biobank: a prospective population-based cohort study. BMJ Open. 2019;9(10):e030318. doi:10.1136/bmjopen-2019-030318

109. Triebner K, Matulonga B, Johannessen A, et al. Menopause is associated with accelerated lung function decline. Am J Respir Crit Care Med. 2017;195(8):1058-1065. doi:10.1164/rccm.201605-0968OC

110. Campbell B, Bui DS, Simpson JA, et al. Early age at natural menopause is related to lower post-bronchodilator lung function. A longitudinal population-based study. Ann Am Thorac Soc. 2020;17(4):429-437. doi:10.1513/AnnalsATS.201902-180OC

111. van der Plaat DA, Pereira M, Pesce G, et al. Age at menopause and lung function: a Mendelian randomisation study. Eur Respir J. 2019;54 (4):1802421. doi:10.1183/13993003.02421-2018

112. Lam SM, Huang SC. Premenstrual asthma: report of a case with hormonal studies. J Microbiol Immunol Infect. 1998;31(3):197-199.

113. Matsuo N, Shimoda T, Matsuse H, Kohno S. A case of menstruation-associated asthma: treatment with oral contraceptives. Chest. $1999 ; 116$ (1):252-253. doi:10.1378/chest.116.1.252

114. Derimanov GS, Oppenheimer J. Exacerbation of premenstrual asthma caused by an oral contraceptive. Ann Allergy Asthma Immunol. 1998;81 (3):243-246. doi:10.1016/S1081-1206(10)62820-7

115. Tan KS, McFarlane LC, Lipworth BJ. Modulation of airway reactivity and peak flow variability in asthmatics receiving the oral contraceptive pill. Am J Respir Crit Care Med. 1997;155(4):1273-1277. doi:10.1164/ajrccm.155.4.9105066

116. Mandhane PJ, Hanna SE, Inman MD, et al. Changes in exhaled nitric oxide related to estrogen and progesterone during the menstrual cycle. Chest. 2009;136(5):1301-1307. doi:10.1378/chest.09-0604

117. Salam MT, Wenten M, Gilliland FD. Endogenous and exogenous sex steroid hormones and asthma and wheeze in young women. $J$ Allergy Clin Immunol. 2006;117(5):1001-1007. doi:10.1016/j.jaci.2006.02.004

118. Nwaru BI, Tibble H, Shah SA, et al. Hormonal contraception and the risk of severe asthma exacerbation: 17-year population-based cohort study. Thorax. 2021;76(2):109-115. doi:10.1136/thoraxjnl-2020-215540 
119. Kos-Kudła B, Ostrowska Z, Marek B, Ciesielska-Kopacz N, Kajdaniuk D, Kudła M. Effects of hormone replacement therapy on endocrine and spirometric parameters in asthmatic postmenopausal women. Gynecol Endocrinol. 2001;15(4):304-311. doi:10.1080/gye.15.4.304.311

120. Lieberman D, Kopernik G, Porath A, Lazer S, Heimer D. Sub-clinical worsening of bronchial asthma during estrogen replacement therapy in asthmatic post-menopausal women. Maturitas. 1995;21(2):153-157. doi:10.1016/0378-5122(94)00890-J

121. Hepburn MJ, Dooley DP, Morris MJ. The effects of estrogen replacement therapy on airway function in postmenopausal, asthmatic women. Arch Intern Med. 2001;161(22):2717-2720. doi:10.1001/archinte.161.22.2717

122. Sedgwick P. Before and after study designs. BMJ. 2014;349:g5074. doi:10.1136/bmj.g5074

123. Sterne JAC, Hernán MA, McAleenan A, Reeves BC, Higgins JPT. Chapter 25: assessing risk of bias in a non-randomized study. In: Higgins JPT, Thomas J, Chandler J, et al., editors. Cochrane Handbook for Systematic Reviews of Interventions. 2nd ed. Chichester (UK): John Wiley \& Sons; 2019:621-642.

124. Nwaru BI, Shah SA, Tibble H, et al. Hormone replacement therapy and risk of severe asthma exacerbation in perimenopausal and postmenopausal women: 17-year national cohort study. J Allergy Clin Immunol Pract. 2021;9(7):2751-2760. doi:10.1016/j.jaip.2021.02.052

125. DeBoer MD, Phillips BR, Mauger DT, et al. Effects of endogenous sex hormones on lung function and symptom control in adolescents with asthma. BMC Pulm Med. 2018;18(1):58. doi:10.1186/s12890-018-0612-x

126. Russell RJ, Brightling C. Pathogenesis of asthma: implications for precision medicine. Clin Sci. 2017;131(14):1723-1735. doi:10.1042/ CS20160253

127. Fahy JV. Type 2 inflammation in asthma-present in most, absent in many. Nat Rev Immunol. 2015;15(1):57-65. doi:10.1038/nri3786

128. Papi A, Brightling C, Pedersen SE, Reddel HK. Asthma. Lancet. 2018;391(10122):783-800. doi:10.1016/S0140-6736(17)33311-1

129. Lambrecht BN, Hammad H. The immunology of asthma. Nat Immunol. 2015;16(1):45-56. doi:10.1038/ni.3049

130. Yung JA, Fuseini H, Newcomb DC. Hormones, sex, and asthma. Ann Allergy Asthma Immunol. 2018;120(5):488-494. doi:10.1016/j. anai.2018.01.016

131. Fuseini H, Newcomb DC. Mechanisms driving gender differences in asthma. Curr Allergy Asthma Rep. 2017;17(3):19. doi:10.1007/s11882017-0686-1

132. Keselman A, Heller N. Estrogen signaling modulates allergic inflammation and contributes to sex differences in asthma. Front Immunol. 2015;6:568. doi:10.3389/fimmu.2015.00568

133. Cephus JY, Stier MT, Fuseini H, et al. Testosterone attenuates group 2 innate lymphoid cell-mediated airway inflammation. Cell Rep. 2017;21 (9):2487-2499. doi:10.1016/j.celrep.2017.10.110

134. Malmhäll C, Weidner J, Rådinger M. MicroRNA-155 expression suggests a sex disparity in innate lymphoid cells at the single-cell level. Cell Mol Immunol. 2020;17(5):544-546. doi:10.1038/s41423-019-0303-4

135. Newcomb DC, Cephus JY, Boswell MG, et al. Estrogen and progesterone decrease let-7f microRNA expression and increase IL-23/IL-23 receptor signaling and IL-17A production in patients with severe asthma. J Allergy Clin Immunol. 2015;136(4):1025-1034. doi:10.1016/j. jaci.2015.05.046

136. Warren KJ, Sweeter JM, Pavlik JA, et al. Sex differences in activation of lung-related type 2 innate lymphoid cells in experimental asthma. Ann Allergy Asthma Immunol. 2017;118(2):233-234. doi:10.1016/j.anai.2016.11.011

137. Takeda M, Tanabe M, Ito W, et al. Gender difference in allergic airway remodelling and immunoglobulin production in mouse model of asthma. Respirology. 2013;18(5):797-806. doi:10.1111/resp.12078

138. Blacquière MJ, Hylkema MN, Postma DS, Geerlings M, Timens W, Melgert BN. Airway inflammation and remodeling in two mouse models of asthma: comparison of males and females. Int Arch Allergy Immunol. 2010;153(2):173-181. doi:10.1159/000312635

139. Melgert BN, Postma DS, Kuipers I, et al. Female mice are more susceptible to the development of allergic airway inflammation than male mice. Clin Exp Allergy. 2005;35(11):1496-1503. doi:10.1111/j.1365-2222.2005.02362.x

140. Antunes MA, Abreu SC, Silva AL, et al. Sex-specific lung remodeling and inflammation changes in experimental allergic asthma. $J$ Appl Physiol. 2010;109(3):855-863. doi:10.1152/japplphysiol.00333.2010

141. Hayashi T, Adachi Y, Hasegawa K, Morimoto M. Less sensitivity for late airway inflammation in males than females in BALB/c mice. Scand $J$ Immunol. 2003;57(6):562-567. doi:10.1046/j.1365-3083.2003.01269.x

142. Fuseini H, Yung JA, Cephus JY, et al. Testosterone decreases house dust mite-induced type 2 and IL-17A-mediated airway inflammation. $J$ Immunol. 2018;201(7):1843-1854. doi:10.4049/jimmunol.1800293

143. Laffont S, Blanquart E, Savignac M, et al. Androgen signaling negatively controls group 2 innate lymphoid cells. J Exp Med. 2017;214 (6): 1581-1592. doi: $10.1084 /$ jem.20161807

144. Corteling R, Trifilieff A. Gender comparison in a murine model of allergen-driven airway inflammation and the response to budesonide treatment. BMC Pharmacol. 2004;4:4. doi:10.1186/1471-2210-4-4

145. Riffo-Vasquez Y, Ligeiro de Oliveira AP, Page CP, Spina D, Tavares-de-lima W. Role of sex hormones in allergic inflammation in mice. Clin Exp Allergy. 2007;37(3):459-470. doi:10.1111/j.1365-2222.2007.02670.x

146. Ligeiro de Oliveira AP, Peron JP, Santos Franco AL, et al. Ovariectomized OVA-sensitized mice display increased frequency of CD4(+)Foxp3 (+) T regulatory cells in the periphery. PLoS One. 2013;8(6):e65674. doi:10.1371/journal.pone.0065674

147. Fuentes N, Nicoleau M, Cabello N, et al. 17ß-Estradiol affects lung function and inflammation following ozone exposure in a sex-specific manner. Am J Physiol Lung Cell Mol Physiol. 2019;317(5):L702-1716. doi:10.1152/ajplung.00176.2019

148. Matsubara S, Swasey CH, Loader JE, et al. Estrogen determines sex differences in airway responsiveness after allergen exposure. Am $J$ Respir Cell Mol Biol. 2008;38(5):501-508. doi:10.1165/rcmb.2007-02980C

149. Degano B, Prévost MC, Berger P, et al. Estradiol decreases the acetylcholine-elicited airway reactivity in ovariectomized rats through an increase in epithelial acetylcholinesterase activity. Am J Respir Crit Care Med. 2001;164(10 Pt 1):1849-1854. doi:10.1164/ ajrccm.164.10.2102009

150. Kalidhindi RSR, Ambhore NS, Bhallamudi S, Loganathan J, Sathish V. Role of estrogen receptors $\alpha$ and $\beta$ in a murine model of asthma: exacerbated airway hyperresponsiveness and remodeling in ER $\beta$ knockout mice. Front Pharmacol. 2019;10:1499. doi:10.3389/ fphar.2019.01499

151. Cephus JY, Gandhi VD, Shah R, et al. Estrogen receptor- $\alpha$ signaling increases allergen-induced IL-33 release and airway inflammation. Allergy. 2021;76(1):255-268. doi:10.1111/all.14491 
152. Carey MA, Card JW, Bradbury JA, et al. Spontaneous airway hyperresponsiveness in estrogen receptor-alpha-deficient mice. Am J Respir Crit Care Med. 2007;175(2):126-135. doi:10.1164/rccm.200509-1493OC

153. Ambhore NS, Kalidhindi RSR, Loganathan J, Sathish V. Role of differential estrogen receptor activation in airway hyperreactivity and remodeling in a murine model of asthma. Am J Respir Cell Mol Biol. 2019;61(4):469-480. doi:10.1165/rcmb.2018-03210C

154. Hellings PW, Vandekerckhove P, Claeys R, Billen J, Kasran A, Ceuppens JL. Progesterone increases airway eosinophilia and hyper-responsiveness in a murine model of allergic asthma. Clin Exp Allergy. 2003;33(10):1457-1463. doi:10.1046/j.1365-2222.2003.01743.x

155. Mitchell VL, Gershwin LJ. Progesterone and environmental tobacco smoke act synergistically to exacerbate the development of allergic asthma in a mouse model. Clin Exp Allergy. 2007;37(2):276-286. doi:10.1111/j.1365-2222.2007.02658.x

156. Fuseini H, Cephus JY, Wu P, et al. ER $\alpha$ signaling increased IL-17A production in Th17 cells by upregulating IL-23R expression, mitochondrial respiration, and proliferation. Front Immunol. 2019;10:2740. doi:10.3389/fimmu.2019.02740

157. Tam A, Wadsworth S, Dorscheid D, Man SF, Sin DD. Estradiol increases mucus synthesis in bronchial epithelial cells. PLoS One. 2014;9(6): e100633. doi:10.1371/journal.pone.0100633

158. Choi HJ, Chung YS, Kim HJ, et al. Signal pathway of 17beta-estradiol-induced MUC5B expression in human airway epithelial cells. Am J Respir Cell Mol Biol. 2009;40(2):168-178. doi:10.1165/rcmb.2007-0377OC

159. Bhallamudi S, Connell J, Pabelick CM, Prakash YS, Sathish V. Estrogen receptors differentially regulate intracellular calcium handling in human nonasthmatic and asthmatic airway smooth muscle cells. Am J Physiol Lung Cell Mol Physiol. 2020;318(1):L112-1124. doi:10.1152/ ajplung.00206.2019

160. Yu CK, Liu YH, Chen CL. Dehydroepiandrosterone attenuates allergic airway inflammation in Dermatophagoides farinae-sensitized mice. $J$ Microbiol Immunol Infect. 2002;35(3):199-202.

161. Liou CJ, Huang WC. Dehydroepiandrosterone suppresses eosinophil infiltration and airway hyperresponsiveness via modulation of chemokines and Th2 cytokines in ovalbumin-sensitized mice. J Clin Immunol. 2011;31(4):656-665. doi:10.1007/s10875-011-9529-3

162. Wenzel SE, Robinson CB, Leonard JM, Panettieri RA. Nebulized dehydroepiandrosterone-3-sulfate improves asthma control in the moderateto-severe asthma results of a 6-week, randomized, double-blind, placebo-controlled study. Allergy Asthma Proc. 2010;31(6):461-471. doi:10.2500/aap.2010.31.3384

163. Chowdhury NU, Guntur VP, Newcomb DC, Wechsler ME. Sex and gender in asthma. Eur Respir Rev. 2021;30(162):210067. doi:10.1183/ 16000617.0067-2021

164. Ciudad-Gutiérrez P, Fernández-Rubio B, Guisado-Gil AB. Gender bias in clinical trials of biological agents for severe asthma: a systematic review. PLoS One. 2021;16(9):e0257765. doi:10.1371/journal.pone.0257765

165. Bousquet J, Cabrera P, Berkman N, et al. The effect of treatment with omalizumab, an anti-IgE antibody, on asthma exacerbations and emergency medical visits in patients with severe persistent asthma. Allergy. 2005;60(3):302-308. doi:10.1111/j.1398-9995.2004.00770.x

166. Busse WW, Paggiaro P, Muñoz X, et al. Impact of baseline patient characteristics on dupilumab efficacy in type 2 asthma. Eur Respir J. 2021;58 (4):2004605. doi:10.1183/13993003.04605-2020

167. Pavord ID, Korn S, Howarth P, et al. Mepolizumab for severe eosinophilic asthma (DREAM): a multicentre, double-blind, placebo-controlled trial. Lancet. 2012;380(9842):651-659. doi:10.1016/S0140-6736(12)60988-X

168. Ferguson GT, FitzGerald JM, Bleecker ER, et al. Benralizumab for patients with mild to moderate, persistent asthma (BISE): a randomised, double-blind, placebo-controlled, phase 3 trial. Lancet Respir Med. 2017;5(7):568-576. doi:10.1016/S2213-2600(17)30190-X

169. Bleecker ER, FitzGerald JM, Chanez P, et al. Efficacy and safety of benralizumab for patients with severe asthma uncontrolled with high-dosage inhaled corticosteroids and long-acting $\beta(2)$-agonists (SIROCCO): a randomised, multicentre, placebo-controlled phase 3 trial. Lancet. 2016;388(10056):2115-2127. doi:10.1016/S0140-6736(16)31324-1

170. FitzGerald JM, Bleecker ER, Nair P, et al. Benralizumab, an anti-interleukin-5 receptor $\alpha$ monoclonal antibody, as add-on treatment for patients with severe, uncontrolled, eosinophilic asthma (CALIMA): a randomised, double-blind, placebo-controlled phase 3 trial. Lancet. 2016;388 (10056):2128-2141. doi:10.1016/S0140-6736(16)31322-8

171. Panettieri RA, Welte T, Shenoy KV, et al. Onset of effect, changes in airflow obstruction and lung volume, and health-related quality of life improvements with benralizumab for patients with severe eosinophilic asthma: phase IIIb randomized, controlled trial (SOLANA). $J$ Asthma Allergy. 2020;13:115-126. doi:10.2147/JAA.S240044

Journal of Asthma and Allergy

Dovepress

\section{Publish your work in this journal}

The Journal of Asthma and Allergy is an international, peer-reviewed open-access journal publishing original research, reports, editorials and commentaries on the following topics: Asthma; Pulmonary physiology; Asthma related clinical health; Clinical immunology and the immunological basis of disease; Pharmacological interventions and new therapies. The manuscript management system is completely online and includes a very quick and fair peer-review system, which is all easy to use. Visit http://www.dovepress.com/testimonials.php to read real quotes from published authors.

Submit your manuscript here: https://www.dovepress.com/journal-of-asthma-and-allergy-journal 